\title{
KAJIAN ETNOPEDAGOGI TERHADAP YOGA SEBAGAI TRADISI BALI
}

\author{
Oleh:
}

\author{
Made Adi Nugraha Tristaningrat \\ STAH Negeri Mpu Kuturan Singaraja
}

Email: adinugraha817@gmail.com

\begin{abstract}
Teaching yoga is not a teaching which is concerned specifically about the teachings of a particular religion or belief. Yoga literally comes from the word "yuj" which means uniting or connecting with God. Yoga is basically a means or way of life, not something out of life, is not it also distanced itself from the activities, but rather is an efficient performance by the true spirit of life. Yoga nor run away from home and habits of human life, but instead is a process of the formation of attitude to life at home (family) as well as social life with order and tradition that followed included also in the scope of Balinese tradition in particular. Yoga in the tradition of Bali are reflected in all the viable commonplace example done in Yoga known there is a term which is a type of yoga Asanas in terms of movement both in the standing position, sitting, and lying down. Asanas indirectly has done in a civic order Bali through sitting cross-legged when visited, lined up neatly, to carry out the process of worship that uses or standing cross-legged stance. This behavior does not necessarily constitute the heritage of our Yoga Science adoption directly or indirectly in everyday life, but it is an idea that something that reflects the local wisdom has the feel a clear education as a meaningful review.
\end{abstract}

Keywords: Balinese tradition, Local wisdom, Yoga.

\section{Abstrak:}

Ajaran Yoga bukanlah khusus tentang agama atau keyakinan tertentu. Yoga berasal dari akar kata 'yuj'yang artinya penyatuan atau menghubungkan diri dengan Tuhan. Secara prinsip Yoga adalah sebuah alat atau cara hidup, yang juga tidak jauh berbeda dengan aktifitas keseharian, tetapi justru sesuatu yang bersifat efisien bagi keberlangsungan spirit kehidupan sehari-hari yang benar. Yoga tidaklah lari dari rumah atau kebiasaan hidup manusia, melainkan sebagai sebuah proses pendeasaan bagaimana menjadi baik dalam rumah tangga dan juga kehidupan social termasuk adat dan tradisi Hindu di Bali. Yoga dalam tradisi adat di Bali direflksikan dalam berbagai bentuk kehidupan yang tidak hanya pada gerakan asana seperti postur berdiri, duduk dan telentang. Asana secara langsung dilakukan ketika mereka sedang duduk dengan bersila atau menyilangkan kakinya untuk melakukan pemujaan, atau berdiri dengan tegak untuk melaksanakan doa. Perilaku seperti ini hendaknya tidak hanya menjadi pelengkap saja dalam dalam sains Yoga, melainkan memang telah hadir secara alami yang merupakan produk local yang memiliki nilai tinggi.

Kata Kunci: Tradisi Bali, tradisi local, yoga

\section{PENDAHULUAN}

Semakin berkembangnya Yoga dianggap pertanda untuk kebangkitan Hindu di Indonesia, dibuktikan dengan adanya sebagian umat dari berbagai agama mulai berpaling ke yoga dan meditasi. Di Indonesia saat ini, mereka-mereka yang tertarik kepada yoga pada umumnya terdiri dari orang-orang yang memang gemar pada kesehatan dan hal-hal yang bersifat spiritual.
Ajaran yoga bukanlah sebuah ajaran yang menyangkut khusus tentang ajaran agama atau kepercayaan tertentu. Yoga adalah teknik pendekatan diri dengan Tuhan yang umumnya jauh lebih tua dari agama apapun di dunia ini, termasuk agama hindu yang merupakan agama tertua sepanjang sejarah manusia. Hindu adalah agama yang berdasarkan atas ajaran Veda. Kitab Veda ini digubah sekitar 5000 tahun sebelum masehi, yaitu pada saat masuknya bangsa Arya ke 
India. Namun yoga sudah dikenal oleh masyarakat india jauh sebelum Veda itu digubah atau yoga itu sudah dikenal jauh sebelum masuknya bangsa Arya ke india. Sebelum jaman Veda, para yogi sudah terdapat di india. Timbulnya ajaran yoga bermula dari kesadaran manusia akan pentingnya mendekatkan diri dengan sang pencipta. Sadar akan adanya kekurangan dan kelemahan, dan juga sadar bahwa atman yang ada dalam diri manusia itu adalah sama dengan Sang Pencipta, hanya saja segala bentuk kekotoran yang melekat pada atman itu harus dibersihkan agar dapat menyatu dengan sempurna pada asalnya, yaitu dengan jalan yoga. Yoga adalah milik dunia luas, milik semua insan manusia yang memiliki kesadaran untuk mendekatkan diri dengan sang pencipta. Ibarat matahari siapun juga bisa dan berhak untuk berjemur dibawahnya.

Yoga secara harfiah berasal dari suku kata "yuj" yang memiliki arti menyatukan atau menghubungkan diri dengan Tuhan. Kemudian Patanjali memberikan definisi tentang yoga yaitu mengendalikan gerak-gerak pikiran. Ada dua hal yang penting sebagai seorang praktisi yoga adalah melatih secara terus menerus sekaligus tidak terikat dengan hal-hal duniawi. Secara spiritual Yoga merupakan suatu proses di mana identitas jiwa individual dan jiwa Hyang Agung disadari oleh seorang yogi, Yogi adalah orang yang menjalani yoga, orang yang telah mencapai persatuan dengan Hyang Agung. Jiwa manusia dibawa kepada kesadaran akan hubungan yang dekat dengan sumber realitas (Hyang Widhi). Seperti setitik air yang bersatu dengan air di samudra. Yoga adalah ketenangan hati, ketentraman, keahlian dalam bertingkah laku, Segala sesuatu yang terbaik dan tertinggi yang dapat dicapai dalam hidup ini adalah Yoga juga, Yoga mencakup seluruh aplikasi yang inklusif dan universal yang mengantar kepada pengembangan/ pembangunan seluruh badan, pikiran dan jiwa.

Yoga merupakan penghubungan atau pengaitan dengan Tuhan yang Maha Tunggal.
Gagasan tentang yoga bertolak dari adanya satuan - satuan individu yang sadar dan biasanya terkenal sebagai "diri rendah", "diri sejati", dan "jiwa" yang umumnya berhasrat untuk dihubungkan dengan Tuhan yang Maha Esa dan tak terhingga. Perpisahan diri sejati bersifat sementara dan disebabkan oleh ketidak tahuan atau Avidya.

Di jaman global sekarang ini sangatlah diperlukan segala sesuatu yang bersifat pemulihan kesadaran diri. Sebab dengan segala bentuk kecanggihan yang ada, terkadang mengantar seseorang ke dalam jalan yang menyimpang dari jalan dharma. Seperti yang dijelaskan dalam kitab Purana, bahwa jaman ini dibagi atau digolongkan ke dalam empat kategori jaman, yaitu jaman Satyayuga, Tretayuga, Dvaparayuga, dan Kaliyuga. Dijaman kaliyuga inilah kehidupan dikatakan paling hancur dari jaman - jaman sebelumnya. Maka dari itu, pada jaman seperti ini diperlukan sebuah kesadaran guna lebih mendekatkan diri kepada Hyang Maha Tunggal.

Salah satu upaya dilakukan agar seseorang memiliki kesadaran diri adalah dengan menempuh jalan yoga. Dengan beryoga orang akan senantiasa berada pada kesadaran diri, mengetahui siapa sebenarnya diri itu, serta apa sebenarnya tujuan manusia dan makhluk lainnya itu diciptakan. Dari yoga orang - orang akan mengerti arti dari setiap kasih, bagaimana menyayangi, dan bagaimana menggunakan cinta kasih tersebut. Karena Tuhan berada pada setiap kasih.

Yoga pada dasarnya adalah sebuah cara atau jalan hidup, bukan sesuatu yang keluar dari kehidupan, bukan pula menjauhkan diri dari aktifitas, melainkan merupakan performa yang efisien dengan semangat hidup yang benar. Yoga bukan pula melarikan diri dari rumah dan kebiasaan hidup manusia, melainkan merupakan suatu proses pembentukan sikap untuk hidup di rumah (keluarga) maupun hidup bermasyarakat dengan suatu pengertian baru, Yoga bukan memalingkan dari kehidupan, tapi merupakan spiritual dari hidup. 


\section{PEMBAHASAN}

\section{a. Ajaran Yoga}

Yoga adalah salah satu jalan keselamatan dalam Hinduisme, yaitu cara mencapai Moksa atau kelepasan. Yoga berarti usaha mendisiplin diri untuk merealisasikan kehadiran Tuhan dalam diri, dan juga berarti usaha mengatur kekuatan alam dari roh, dan juga sebagai usaha penyatuan diri. Yoga merupakan salah satu dari enam ajaran dalam filsafat Hindu, yang menitikberatkan pada aktivitas meditasi atau tapa di mana seseorang memusatkan seluruh pikiran untuk mengontrol panca inderanya dan tubuhnya secara keseluruhan. Masyarakat global umumnya mengenal Yoga sebagai aktifitas latihan utamanya asana (postur) bagian dari Hatta Yoga. Yoga juga digunakan sebagai salah satu pengobatan alternatif, biasanya hal ini dilakukan dengan latihan pernapasan, oleh tubuh dan meditasi, yang telah dikenal dan dipraktekkan selama lebih dari 5000 tahun. Sedangkan pengertian Yoga menurut Ensiklopedi umum adalah sistim ajaran gaib yang diperkembangkan Hinduisme dengan maksud membebaskan orang dari dunia khayalan seperti yang difahami dengan pancaindera. Pembebasan ini sukar dan mungkin memerlukan beberapa kali umur hidup. Yogi (penganut yoga) yang percaya akan pantheisme (kepercayaan bahwa dunia dengan segala isinya adalah Tuhan) mencari persatuan dengan jiwa seluruh alam dunia. Penganut yoga yang atheis (tidak mengakui adanya Tuhan) mencari perasingan yang sempurna dari segala jiwa-jiwa lainnya dan pengetahuan diri sendiri yang sempurna. Kemudian terakhir yang dicari ialah kemuliaan penerangan sempurna. Para penganut yoga memakai disiplin jasmani untuk mencapai penyucian, kebersihan, samadi, dan latihan. Orang yang melakukan tapa yoga disebut yogi, yogin bagi praktisi pria dan yogini bagi praktisi wanita. Sastra Hindu yang memuat ajaran Yoga, diantaranya adalah Upaishad, Bhagavad Gita, Yogasutra, Hatta Yoga serta beberapa sastra lainnya. Klasifikasi ajaran Yoga tertuang dalam
Bhagavad Gita, diantaranya adalah Karma Yoga/ Marga, Jnana Yoga/Marga, Bakti Yoga/Marga, Raja Yoga/Marga.

Jadi dapat disimpulkan bahwa Yoga sebagai sebuah cara atau jalan untuk mengendalikan pikiran yang terobyektifkan serta kecendrungan alami pikiran dan mengatur segala kegelisahankegelisahan pikiran agar tetap tak terpengaruh sehingga bisa mencapai penyatuan antara kesadaran unit dan kesadaran kosmik.

Sejak lebih dari 5000 tahun yang lalu, yoga telah diketahui sebagai salah satu alternatif pengobatan melalui pernafasan. Awal mula munculnya yoga diprakarsai oleh Maharsi Patanji, dan menjadi ajaran yang diikuti banyak kalangan umat Hindu. Cittavrttinirodha adalah kata yang dianggap dapat mengartikan yoga yang sesungguhnya. Artinya sendiri adalah penghentian gerak pikiran. Ajaran yoga ini ditulis Maharsi lewat sastra yoga sutra, yang terbagi menjadi empat dan memuat 194 sutra. Bagian-bagian pada sastra, yaitu Samadhipada (bagian pertama), Sadhapada (bagian kedua), Vidhutipada (bagian ketiga), dan Kailvalyapada (bagian keempat). Ajaran Yoga ternyata juga termuat dalam sastra Hindu. Beberapa sastra Hindu tersebut adalah Upanisad, Bhagavad Gita, Yogasutra, dan Hatta Yoga. Kemudian, ajaran yoga mengalami pengklasifikasian, yang terdapat pada sastra Hindu, dalam Bhagavad gita dapat diklasifikasi sebagai berikut: (1) Hatha Yoga, yaitu yoga yang dilakukan dengan pose fisik (Asana), teknik pernafasan (Pranayana) disertai dengan meditasi. Ketiga poin ini dilakukan untuk membuat pikiran menjadi tenang dan tubuh sehat penuh vitalitas. (2) Bhakti Yoga, yaitu yoga yang memfokuskan diri untuk menuju hati. Jika seorang yogi berhasil menerapkannya, maka dia akan dapat melihat kelebihan orang lain dan cara untuk menghadapi sesuatu. Keberhasilan yoga ini juga membuat yogis menjadi lebih welas asih dan menerima segala yang ada di sekitarnya, karena dalam yoga ini diajarkan untuk mencintai alam dan beriman kepada Tuhan. (3) Raja Yoga, 
yaitu yoga yang menitikberatkan pada teknik meditasi dan kontemplasi. Yoga ini nantinya akan mengarah pada cara penguasaan diri sekaligus menghargai diri sendiri dan sekitarnya. Raja yoga merupakan dasar dari yoga sutra. (4) Jnana Yoga, yaitu yoga yang menerapkan metode untuk meraih kebijaksanaan dan pengetahuan. Teknik ini cenderung untuk menggabungkan antara kepandaian dan kebijaksanaan, sehingga nantinya mengdapatkan hidup yang dapat menerima semua filosofi dan agama. (5) Karma Yoga, yaitu yoga ini mempercayai adanya reinkarnasi. Di sini Anda akan dibuat untuk menjadi tidak egois, karena yakin bahwa perilaku Anda saat ini akan berpengaruh pada kehidupan yang akan datang. (6) Tantra Yoga. Untuk yoga ini sedikit berbeda dengan yoga yang lain, bahkan ada yang menganggapnya mirip dengan ilmu sihir. Teknik pada yoga ini terdiri atas kebenaran (kebenaran) dan hal-hal yang mistik (mantra). Tujuan dari teknik ini supaya dapat menghargai pelajaran dan pengalaman hidup.

Dalam masyarakat Indonesia, yoga sudah dikenal luas oleh berbagai kalangan. Kekawin Arjuna Wiwaha (11.1) menyebutkan kata Yoga dengan sangat jelas; "Sasi wimba heneng ghata mesi banu Ndanasing, suci nirmala mesi wulan Iwa mangkana rakwa kiteng kadadin Ring angambeki Yoga kiteng sakala, Bagaikan bulan di dalam tempayan berisi air. Di dalam air yang suci jernih tampaklah bulan. Sebagai itulah Dikau (Tuhan) dalam tiap mahluk. Kepada orang yang melakukan Yoga Engkau menampakkan diri”. Jadi pada dasarnya semua aliran kepercayaan yang menjadikan Yoga atau Meditasi sebagai pegangan utamanya pada dasarnya adalah pengikut ajaran Veda.

Maharsi Patanjali adalah pelopor ajaran Yoga yang merupakan bagian dari filsafat Hindu yaitu Sad Darsana. Buku beliau yang bernama Yogasutra terdiri dari empat bagian yaitu: (1) Samadhipada, tentang sifat, tujuan dan bentuk ajaran yoga yang menjelaskan adanya perubahan-perubahan pikiran dalam melakukan yoga. (2) Sadhanapada, tentang tahapan-tahapan pelaksanan yoga, cara mencapai samadhi dan pahala yang akan didapat oleh mereka yang telah mencapai samadhi. (3) Wibhutipada, tentang hal-hal yang bersifat bathiniah, kekuatan bathin yang didapat oleh mereka yang melaksanakan yoga. (4) Kaiwalyapada, tentang alam kelepasan dan keadaan jiwa yang telah dapat mengatasi keterikatan pada keduniawian.

Tujuan yang ingin dicapai dalam melaksanakan yoga adalah pencapaian moksa melalui kesadaran yang disebut sebagai "wiwekajnana" yaitu pengetahuan tentang apa yang salah dan apa yang benar menurut ajaran Hindu. Sebagaimana telah diuraikan dalam Jnana Marga, maka dapatlah dikatakan bahwa Jnana Marga adalah dasar fundamental bagi Yoga Marga, karena untuk mencapai kesadaran Wiwekajnana para siswa haruslah mempelajari Weda, Upanisad, Smrti, Itihasa dan Purana. Hal ini ditegaskan oleh Maharsi Patanjali bahwa kelepasan dari ikatan duniawi dapat dicapai melalui pengetahuan langsung terhadap perbedan atman/jiwa dengan hal-hal yang bersifat jasmani seperti badan, pikiran dan sifat ke-akuan kemudian mewujudkannya melalui pengendalian fungsi indria, pengendalian pikiran, dan pengendalian “aku”. Yoga dilaksanakan melalui delapan tahapan dikenal dengan nama "Astangga-yoga" yaitu: (1) Yama: Kontrol etis, perlakuan kita terhadap faktor eksternal dalam kehidupan. (2) Niyama: Penguasaan spiritual dalam memelihara kemurnian hidup sebagai manusia ciptaan Tuhan. (3) Asana: Rangkaian gerak postur untuk melatih serta memelihara juga meningkatkan fungsi seluruh bagian tubuh. (4) Pranayama: Seni pernapasan yang mampu meningkatkan kualitas kehidupan secara menyeluruh. (5) Pratyahara: Penguasaan diri yang bersifat internal. Kemampuan untuk fokus terhadap apa yang ada dalam 'diri seorang manusia. (6) Dharana: Konsentrasi, apabila kita mampu memelihara fokus tadi secara lebih intens. (7) Dhyana: Sebuah level di mana fokus 
tadi menjadi sesuatu yang bersifat otomatis, panjang namun tanpa beban. Pelakunya mampu membuat diri mereka fokus penuh konsentrasi namun terlihat luar biasa relaks serta nyaman. (8) Samedhi: Saat semua pencapaian positif tersebut telah termanifestasi dalam semua aspek kehidupan sang manusia pelaku yoga.

Secara garis besar Yoga ada 4 jenis, yaitu:

(1) Karma Yoga adalah yoga yang dilakukan melalui kehidupan tanpa pamrih. Para praktisinya tidak pernah mengeluh menghadapi persoalan. Semua masalah dipandang merupakan akibat dari karma, maka harus diterima dan dihadapi. Konsep ini banyak disalah-pahami sebagai konsep hidup pasip, padahal konsep ini justru membawa manusia menjadi aktif dalam menghadapi kehidupan. Karma Yoga mengajarkan pada manusia untuk menghadapi dan menyelesaikan persoalan, bukan melarikan diri dari persoalan. Bila anda praktisi Karma Yoga, maka persoalan apapun yang terjadi harus anda terima, tidak melarikan diri. Melarikan diri bukan solusi, tapi justru menimbun persoalan dan membuat persoalan baru. Persoalan tidak akan pernah hilang, yang ada hanyalah penundaan dan penumpukan. Untuk menyelesaikannya, mau - tidak mau, sukaterpaksa, semua harus dihadapi. Entah kapan, yang jelas semua persoalan perlu penyelesaian. Banyak penderita stress, bahkan yang bunuh diri, dikarenakan tidak mau menerima suatu persoalan sebagai kenyataan dan menyelesaikannya, kemudian melarikan diri tanpa mau menghadapi dan menyelesaikannya.

(2) Bakti Yoga adalah yoga yang dilakukan dengan berbakti kepada Tuhan, yaitu melaksanakan perintah dan menjauhi larangan Tuhan. Semuanya dilakukan dengan cinta tanpa memiliki pamrih apa pun (termasuk ingin masuk sorga). Kecintaan praktisi Bakti Yoga (Bakta) bermakna luas. Bukan hanya pada Tuhan, namun juga pada semua mahluk ciptaan-NYA. Mencintai ciptaan-NYA merupakan manifestasi dari mencintai Sang Pencipta. Cinta seorang Bakta tidak membeda-bedakan ras, suku, bangsa, dan agama. Tidak membenci yang miskin - yang kaya, yang indah - yang buruk, yang pintar - yang bodoh, yang beriman - yang kafir. Semuanya dicintai, bahkan binatang, tumbuhan, dan batubatuan pun tidak luput dari kecintaan seorang praktisi Bakti.

(3) Jnana Yoga, yoga yang dilakukan dengan jalan pengetahuan. Praktisi yoga ini adalah para intelektual, dengan cara mengkikis kebodohan manusia. Dengan terkikisnya kebodohan, maka manusia semakin pandai. Semakin pandai manusia, terhapuslah kemiskinan, ketidak-adilan, dan kesewenangan. Dengan demikian semakin damai dunia. Semua itu dikarenakan manusia tahu akan hakekat dirinya. Manusia yang tahu hakekat dirinya, maka dia akan tahu hakekat Tuhannya. Itulah tugas para praktisi Jnana Yoga.

(4) Raja Yoga adalah yoga yang dilakukan dengan cara mempraktekkan secara langsung tata cara pengedalian pikiran dan kesadaran indra-indra manusia. Raja Yoga memuat berbagai disiplin fisik dan pikiran, semua dilakukan dalam rangka menuju kepenyatuan seorang hamba dengan Tuhan. Hasil dari semua itu disebut Pencerahan. Perkembangan kemudian, hanya Raja Yoga lah yang dikenal sebagai Yoga. Bagi praktisi Raja Yoga, praktek Hatha, Japa, Mantra, Kundalini, dsb. bukanlah sesuatu yang terpisah. Sebagaimana praktek Sholat, tidak pernah memisahkan antara "bacaan" (doa-doa) dengan "gerakan-gerakannya", semuanya sakral. Seorang praktisi Yoga yang sempurna, juga melakukan praktek 
Bakti, Karma, dan Jnana. Sebagaimana seorang yang taat beragama, tidak hanya melakukan ritual peribadatan pada Tuhan saja, tapi juga melakukan semua aturan moralitas dan hukum yang telah digariskan. Yoga Sutra yang disusun oleh Maharshi Patanjali ini adalah teks klasik terbesar dan terutama dalam aliran filsafat Yoga India. Ia dinyana telah ditulis 2500 tahun lalu; jadi kurang lebih sejaman dengan Buddha Gotama. Bahkan ada yang berpendapat bahwa teks ini telah disusun tak kurang dari abad ke-2 SM. Di dalamnya, sutra-sutra tentang Yoga atau penyatuan universal benar-benar pendek dan akurat; menegaskan secara lengkap, rinci dan akurat bagianbagian yang esensial. Mengingat kepadatan dan kepekatan kandungan makna spiritualfilosofisnya, Yoga Sutra dianjurkan untuk dijelaskan dan di-interpretasikan oleh seorang Guru Yoga melalui komentarkomentar.

Praktek Yoga dipandang sebagai pelengkap dari dan dalam satu kesatuan pandang dengan filsafat Sankhya. Tujuan-pokoknya adalah merealisasikan kebebasan Jiva dari kungkungan Maya.Ketidak-cukupan informasi tentang Yoga telah mengundang tak sedikit persepsi keliru di kalangan awam tentangnya. Yoga seringkali dikacaukan dengan Tapa, atau bahkan dengan sesuatu yang berbau klenik yang mendekati takhyul, atau memandangnya hanya dari sudutpandang kegaiban-kegaiban dan kanuragan saja, telah menggugah penulis untuk menghadirkan buku ini di tengah-tengah kita semua. Untuk ini, ada baiknya diketengahkan paparan Sri Swami Sivananda pendiri The Divine Life Society tentang Yoga. "Yoga bukanlah mengurung diri di dalam gua-gua, bukan pula berkelana di hutanhutan lebat sekitar pegunungan Himalaya. Ia juga bukan hanya memakan jenis makanan yang berupa sayur-mayur dari pegunungan.
Brahman bukanlah pengecut yang lari dari hiruk-pikuknya komunitas dan pemukiman manusia. Praktekkan sajalah Yoga di rumah Anda sendiri. Manakala hasrat untuk mempraktekkannya muncul, ini berarti bahwa kebebasan telah berada dalam jangkauan Anda, oleh karenanya manfaatkanlah peluang ini sebaikbaiknya. Menjalani kehidupan sebagai seorang Yogi, tidaklah mesti menelantarkan siapapun juga atau mengabaikan kewajiban-kewajiban melekat Anda. Ia bermakna merubah sikap hidup dari kebiasaan mengerjakan sesuatu yang sia-sia, menuju jalur yang secara pasti mengantarkan langsung kepada Tuhan. Ia dibarengi dengan perubahan prilaku dalam menjalani kehidupan serta metode-metodenya guna membebaskan diri Anda dari berbagai belenggu dan kemelekatan. Kebenaran dan pengabaian keakuan, sebenarnya merupakan masalah sikap-batin".

Sesuai sistematika dari teks aslinya, Kidung Kelepasan Patanjali inipun disajikan dalam 4 bagian (pãda), masing-masing adalah:

(1) Samãdhi Pãda Hakekat Penyatuan Agung. Pãda yang tersusun dalam 51 sutra ini memaparkan tentang landasan spiritualfilosofis Yoga, hakekat dari penyatuan dan hakekat ketuhanan dalam Yoga. Dalam bagian ini akan banyak kita temukan paparan yang menyangkut intisari keimanan Hindu, yang juga berhampiran dengan Buddha, serta penerangan yang amat bersesuaian dengan Upanishad-upanishad dan Veda Sruti. Dari bagian ini pula, bila kita cermati, kesinambungan antara Sanhkya Darsana dan Vedanta terjembatani dengan Shastrãgamashastrãgama lain. Pãda ini merupakan pembuka yang berisikan pembekalan dalam tahap persiapan, sebagai landasan pijak dan kerangka dasar seorang sadhaka, seorang penekun di jalan spiritual. Samãdhi Pãda terutama menjelaskan beberapa jenis Samãdhi sesuai dengan tersisa atau tidaknya objek di dalam Samãdhi, yang dicapai 
bersama dengan terhentinya pusaranpusaran pikiran. Kaivalya, yang merupakan isu sentral dari Yoga Sutra ini, hanya dicapai melalui Nirvikalpa atau Nirbija Samãdhi. Walaupun demikian, jenis pencapaian lain tetap merupakan pencapaian tinggi yang merupakan penghampiran pra yang tertinggi. Pembekalan mendasar, seperti ketidakmelekatan (vairagya) dan pembiasaan lakuspiritual (abhyasa) juga diberikan, sebelum seorang sadhaka benar-benar terjun dalam praktek kehidupan spiritual secara intens.

(2) Sãdhana Pãda - Paparan Praktis Praktek Spiritual. Pãda yang tersusun dari 55 sutra ini memberikan paparan praktis bagi seorang sadhaka. Disini mulai diperkenalkan Yama, Niyama, Pranayama dan Pratyahara, serta persiapan untuk memasuki tiga-serangkai Samyama, Dharana, Dhyana, Samadhi. Samyama baru dipaparkan secara panjang lebar pada Vibhuti Pãda. Metode pembebasan psikologis dan spiritual yang terdiri dari delapan tahapan ini, juga dikenal dengan Ashtanga Yoga. Disini juga diingatkan akan bahaya dari siddhi bagi seorang sadhaka sejati. Secara keseluruhan prinsip-prinsip praktis dari Yoga dapat ditemukan disini dalam paparan yang lugas. Sebagai paparan praktis, di dalam mengikuti Sãdhana Pãda ini kita juga acapkali seakan-akan sedikit 'dipaksa' untuk mengerti tentang sistem Yoga praktis tertentu, terutama Hatha Yoga dan Laya Yoga atau Kundalini Yoga.

(3) 'Vibhuti Pãda — Paparan tentang Kekuatan dan Kesempurnaan. Disini dipaparkan tuntunan praktis yang lebih tinggi, terutama tentang tiga-serangkai Samyama, melalui mana kekuatan-kekuatan spiritual, kegaiban-kegaiban, hingga kesempurnaan Yoga bisa dicapai. Bagi yang mempunyai naluri mistis yang kuat, bagian yang tersusun oleh 56 sutra ini, bisa merupakan bagian yang paling menarik. Disini juga disampaikan peringatan-peringatan untuk tidak melaksanaan Yoga hanya demi perolehan kekuatankekuatan dan kegaiban-kegaiban itu, apala- gi terikat padanya. Ini dapat dengan mudah menjatuhkan sang penekun.

(4) 'Kaivalya Pãda - Menggapai Kebebasan Sejati. Di antara ke-empat Pãda, Kaivalya Pãda inilah yang tersingkat. Disini paparan terasa padat, yang utamanya difokuskan pada pencapaian Kaivalya dan tentang bagaimana seorang Yogi yang telah mencapai status itu. Disini Patanjali tak lupa menyelipkan lagi tatanan etika-moral luhur dari seorang Yogi Sempurna yang dalam ajaran Vedanta kita kenal sebagai Jivanmukta, ia yang telah terbebaskan dari siklus Samsara dan tak terlahirkan kembali di alam manapun di antara 34 sutra pembentuknya. Jadi, secara keseluruhan, ke-empat Pãda benar-benar membentuk satu kesatuan integral, yang kait-mengait satu sama lain, mengalir dan berlanjut, saling memperjelas dan mempertegas. Ini juga berarti meminta praktisi mempelajari Yoga Sutra guna memperoleh pemahaman yang baik tentang praktek Yoga itu sendiri secara berulang-ulang, bolak-balik ke depan dan kembali ke belakang. Ia memang merupakan manual-praktis yang tersaji dalam satu kesatuan bahasan komprehensif, menyeluruh dan terpadu.

Seseorang yang ingin berlatih yoga asanas yang perlu diketahui pertama kalinya adalah definisi dari asanas itu sendiri asanas menempati urutan ke 3 dari Astanga Yoga. Maharsi Patanjali, di dalam bukunya Swami Satya Prakash Saraswati (1996: 115) membagi Asanas itu ke dalam tiga sutra yaitu:

\section{Sthira sukham - asanam (46) \\ Prayatna - saithilya - ananta samapattibhyam (47) \\ Tato dvandva anabbighatah (48)}

(Sadhana Pada).

"Sthira" berarti stabil tetap tanpa keraguraguan tanpa paksaan tanpa ketegangan. "Prayatna - saithilya" yang berarti suatu keadaan atau kondisi yang tidak ada pengerahan kekuatan khusus badan mengambil sikap tanpa bergerak dan dikuasai penuh. Ananta samapattibyam yaitu seorang praktisi Yoga harus mengambil gerakan- 
gerakan Asanas yang sesuai dengan keadaan tubuhnya. Tato dvandva - anabhighatah artinya seorang praktisi Yoga harus bebas dari pengaruh lingkungan dapat bertahan dalam keadaan panas dingin sakit dan senang terang dan gelap manis dan pahit mewah dan sederhana.

Sedangkan Sarkar (2003:149) menjelaskan bahwa yang dimaksud dengan Asanas adalah berbagai sikap tubuh yang kalem tenang dan mudah yang dilakukan sambil menarik dan membuang nafas dengan tepat dan dalam melakukan gerakan tersebut seseorang merasakan kenyamanan fisik dan mental.

Yoga Asanas melatih berbagai saraf jaringan kelenjar dan organ-organ tubuh manusia. Seseorang yang berlatih Yoga Asanas secara teratur akan menikmati kenyamanan fisik dan ketenangan mentalnya. Latihan Yoga asanas secara teratur menjaga tubuh tetap sehat dan menyembuhkan banyak penyakit. Asanas mengendalikan kelenjar, kelenjar kelenjar ini mengendalikan sekresi hormon, dan sekresi hormon mengendalikan kecenderungan-kecenderungan pikiran. Maka Yoga asanas sangat membantu membantu sadhaka (aspiran yoga) untuk menyeimbangkan tubuh dan mengonsentrasikan pikiran. Jadi dalam asanas faktor ini harus diperhatikan agar betul-betul Yoga Asanas itu akan mengarahkan seseorang ke arah tujuan dari Yoga itu sendiri yaitu samyogo yogo ityukto jiva'tma Prama'tmanah. Inilah tujuan Yoga itu, untuk mencapai tujuan itu asanas harus dilaksanakan sesuai dengan definisi slira sukam asanas, Prayatna saithilya ananta samapattibhyam dan Tato dvandva anabhighatah.

Adapun manfaat asanas menurut Yudhi Widyantoro dalam majalah Nirmala (2000) yaitu untuk melenturkan tubuh sehingga kuat dan sehat, meningkatkan ketangkasan, keseimbangan daya tahan tubuh dan vitalitas serta melatih setiap saraf, otot, dan persendian. Sedangkan Sarkar (2003) mengemukakan bahwa pentingnya seseorang melakukan Asanas karena alasan-alasan berikut antara lain meningkatkan kelenturan tubuh, membetulkan cacat cacat pada kelenjar, dan menyeimbangkan sekresi hormon dengan tujuan mengendalikan kecenderungan-kecenderungan yang ada dalam tubuh manusia, menyeimbangkan tubuh dengan pikiran, menarik pikiran dari pemikiran yang tidak diinginkan, mempersiapkan pikiran bagi meditasi yang lebih halus dan lebih tinggi. Dari kedua Pernyataan diatas disimpulkan bahwa Yoga asanas tidak untuk orang-orang sakit saja, tetapi Yoga Asanas bisa juga dilakukan oleh orang-orang yang tidak mempunyai masalah kesehatan Yoga Asanas bisa dijadikan sebagai alat untuk merilekskan tubuh.

\section{b. Tradisi Bali}

Berbicara tradisi perlu kita sikapi berkaita dengan gejala mendasar yang dirasakan oleh masyarakat Bali dewasa ini yaitu perubahan sosial budaya yang sangat cepat. Perubahan sosial budaya terjadi karena adanya kontak budaya antar negara. Kontak dalam tatanan budaya dapat dimaknai sebagai pertemuan antara nilainilai baru dengan nilai-nilai lama yang saling mendominasi dan sangat berpengaruh dalam tataran surface structure, yakni pada sikap dan pola-pola perilaku, serta dalam tataran deep structure yaitu pada perubahan sistem nilai, pandangan hidup, filsafat, dan keyakinan. Dapat disimpulkan bahwa perubahan pada masyarakat Bali terjadi karena gelombang modernisasi dan globalisasi yang telah memperkenalkan nilai baru dalam lingkungan tradisi Bali. Pesatnya kontak sosial budaya antarprovinsi dan antarnegara terjadi karena kemajuan ilmu pengetahuan dan teknologi (IPTEK), yang ditandai dengan kian mutakhirnya media Informasi dan Teknologi Komunikasi (Information and Communication Technology, ICT). Akselerasi informasi gelombang globalisasi telah menyebabkan dunia seakan-akan menyatu menjadi satu kampung global (global village) dan tersatukannya budaya global yang berasas pada nilai-nilai liberalistikkapitalistik. Dalam keadaan seperti itu, tidak menutup kemungkinan terjadinya homogenisasi 
(penyeragaman budaya) dan neoliberalisasi yang merasuk ke dalam seluruh lini kehidupan termasuk dalam praktek pendidikan. Hal ini berarti bahwa perubahan pada tataran nilai pada masyarakat Bali tidak dapat terelakkan. Apadurai dalam Ritzer (2007) menggambarkan, bahwa perubahan nilai terjadi karena pengaruh (1) perpindahan orang (ethnoscape), (2) media informasi (mediascape), (3) teknologi yang dibawa atau yang dapat dilihat (technocape), (4) terjadinya aliran kepemilikan modal (financesscape), dan (5) ideologiidiologi (ideoscapes) baik yang dibawa, diinformasikan, maupun yang dapat diadopsi. Kondisi ini membawa konsekuensi yang sangat mendasar bagi kehidupan dan upaya mempertahankan kemurnian adat istiadat dan nilai-nilai budaya lokal Bali. Dalam era globalisasi yang terbuka ini, terpaan informasi sangat memungkinkan seseorang mengadopsi nilai-nilai, pengetahuan, dan kebiasaan luar lingkungan sosialnya dan jauh dari jangkauannya secara fisik. Globalisasi ini telah menimbulkan pergulatan antara nilai-nilai budaya lokal dan nilai-nilai budaya global (modern) yang semakin tinggi intensitasnya. Sementara dipahami bahwa nilai-nilai modern tidak selalu membawa kebaikan bagi pengembangan nilai-nilai budaya lokal.

Menurut Croch dalam Nesta (1998), memaparkan tentang konflik sosiokultural yang terjadi di kalangan masyarakat khususnya masyarakat Bali Timur. Dikatakannya, bahwa secara empiris masyarakat Bali di bagian Timur mengalami degradasi nilai-nilai sosio-kultural yang disinyalir disebabkan oleh pengembangan industri pariwisata. Dalam industri pariwisata terjadi "gesekan budaya", "pertukaran budaya" atau "adopsi budaya". Jika budaya yang diadopsi oleh masyarakat Bali tidak sesuai dengan budaya lokal Bali, maka akan terjadi persilangan budaya. Dalam kondisi semacam ini, bisa terjadi pertahanan nilai etika dan budaya lokal yang menjadi pegangan masyarakat Bali akan semakin tergoyahkan, nilai tradisi masyarakat Bali yang ramah, lembut, dan santun bisa tergilas oleh nilainilai baru yang bersandar dan berlindung kepada kebebasan dengan mengatasnamakan hak asasi. Hal ini didukung oleh Fukuyama (1999) yang menyatakan bahwa pertukaran informasi termasuk nilai antarbangsa yang berlangsung dengan cepat dan penuh dinamika, mendorong terjadinya proses perpaduan nilai, kekaburan nilai, bahkan terkikisnya nilai-nilai asli yang sebelumnya sakral dan menjadi identitas suatu bangsa.

Manurut Sauri (2006), ketika nilainilai globalisasi diagung-agungkan oleh para pendukungnya, maka saat itu pula terjadi proses penggiringan nilai-nilai budaya tradisional masyarakat yang pada akhirnya mengakibatkan terjadinya split dan kegamangan nilai. Kegamangan nilai ini juga sangat dirasakan dan dialami sebagian besar masyarakat Bali. Kegamangan nilai yang dialami masyarakat dewasa ini terjadi karena sisi negatif modernisasi dengan lebih mengutamakan kemampuan akal, dengan memarginalkan peranan nilai-nilai transendental serta tunduk pada paham individualisme, materialisme, dan kapitalisme. Akibatnya, terjadi berbagai bentuk penyimpangan nilai moral yang tercermin dalam corak, gaya, dan pola hidup masyarakat. Fenomena menguatnya corak dan gaya hidup masyarakat yang hedonis cukup mengkhawatirkan bagi pelestarian nilainilai lokal, dan memberikan dampak negatif terhadap jati diri orang Bali.

Bali memang menarik dan unik. Selain merupakan salah satu ikon kebanggaan Indonesia yang telah mendatangkan banyak wisatawan dan devisa bagi Indonesia karena lingkungan alam dan budayanya, menurut Tarigan (2011) Bali juga sebagai lokus kehidupan yang unik memiliki banyak cerita yang dinamis sebagai pola kehidupan yang humanis-religius. Keunikan budaya Bali dilandasi oleh nilai-nilai yang bersumber pada ajaran agama Hindu. Masyarakat Bali mengakui adanya oposisi biner yang komplementer dalam konsep rwa-bhineda, yang ditentukan oleh ruang (desa), waktu (kala), dan kondisi riil di lapangan 
(patra). Konsep desa, kala, patra ini menyebabkan kebudayaan Bali bersifat fleksibel dan selektif dalam menerima dan mengadopsi pengaruh budaya luar. Budaya Bali juga memiliki identitas yang jelas yaitu budaya ekspresif yang termanifestasi secara konfiguratif yang mencakup nilai-nilai dasar yang dominan, seperti nilai religius, nilai estetika, nilai solidaritas, nilai harmonis, dan nilai keseimbangan yang tercermin dalam kearifan lokalnya menurut Geriya (2000).

Banyak tokoh dunia yang tertarik menyoroti, mengkaji tentang budaya dan kearifan lokal Bali, bahkan temuannya tersebut dituangkan dalam tulisannya. Clifford (1980) misalnya, dalam bukunya Negara, The Theatre State in Nineteenth Century Bali membahas tentang subak secara mendalam dan sistematis, yang sampai pada kesimpulan bahwa di seluruh dunia tidak ada organisasi sosial pengairan yang seefektif subak. Dalam kaitannya dengan pembentukan karakter dilihat dari sisi fungsi nilai membentuk “isi” manusia, Geertz dalam Triguna (2011) juga pernah menulis tentang pola asuh orang Bali yang menurutnya model pola asuh orang tua telah membentuk karakter orang Bali secara keseluruhan. Demikian juga dengan V.E. Korn (1938) menuangkan kekagumannya tentang orang Bali dalam bukunya Het Adatrecht van Bali (Hukum Adat Bali). Dikatakan bahwa betapa orang Bali piawai dalam membuat saluransaluran air di bawah tanah (bahasa Balinya: aungan), bahkan Korn menyebut mereka sebagai para insinyur Bali. Tidak ketinggalan, dibidang pengobatan tradisional (usada Bali) menjadi daya tarik ilmuan kedokteran berkebangsaan Jerman, seperti Wolfgang Weck. Dalam bukunya Heilkunde und Volkstum auf Bali (1976) (Obstetri dan Cerita Rakyat di Bali) disebutkan bahwa tata cara pengobatan tradisonal Bali memberi sumbangan yang penting bagi metode pengobatan dalam ilmu kedokteran modern.

Gambaran di atas, menunjukkan bahwa ada landasan yang kuat dan segi-segi positip tentang kemampuan orang Bali dengan kebudayaannya yang masih bersifat tradisional. Akan tetapi, dengan banyaknya wisatawan dengan membawa kultur mereka masing-masing, mulai menggoyahkan fondasi yang dibangun sejak awal. Dapat dikatakan bahwa masyarakat Bali kini ada dalam pusaran ideologi modern akibat gelombang globalisasi. Tidak semua nilai-nilai budaya tersebut dapat hidup dan berkembang dengan baik karena terdesak oleh kuatnya arus modernisasi dan globalisasi. Hal ini disebabkan oleh kurangnya pemahaman masyarakat Bali tentang hakikat dan pentingnya peranan budaya lokal Bali menyangkut adat, tradisi, dan nilai-nilai agama Hindu yang menjiwainya. Akibatnya, banyak generasi muda Bali yang melupakan tradisi dan adat budaya Bali yang telah dibangun berabad-abad lamanya oleh nenek moyang orang Bali.

\section{c. Kajian Etnopedagogik}

Istilah etnopedagogi di UPI menurut Suratno (2010) dapat dipandang sebagai suatu pesan terkait dengan dengan istilah budaya-karakter (aspek etno), dan pendidikan keguruan (aspek pedagogi).

Alwasilah, et.al (2009) mengemukakan dalam konteks budaya secara umum, etnopedagogi menaruh perhatian khusus terhadap local genius dan local wisdom dengan mengungkap nilai-nilai budaya Sunda sebagai model awal. Ajip Rosidi (2009) mengingatkan bahwa nilai budaya Sunda modern telah berbaur dengan budaya lainnya. Menurut Kartadinata (2010), terdapat beberapa postulat dikemukakan terkait karakter masyarakat Sunda: hurip, waras, cageur, bageur, bener, pinter, ludeung, silih asah, silih asuh, silih asih, sineger tengah, singer, motekar dan rapekan. Dapat dikatakan bahwa Etnopedagogi memandang pengetahuan atau kearifan lokal (local knowledge, local wisdom) sebagai sumber inovasi dan keterampilan yang dapat diberdayakan demi kesejahteraan masyarakat

Dalam perspektif hakikat pendidikan, menurut Alwasilah (2009) dan Kartadinata (2010) 
memandang bahwa pendidikan tidak terlepas dari aspek sosial dan kultural. Pendidikan bersifat deliberatif dalam arti masyarakat mentransmisikan dan mengabadikan gagasan kehidupan yang baik yang berasal dari kepercayaan masyarakat yang fundamental mengenai hakikat dunia, pengetahuan dan tata. Oleh karena itu, diperlukan reorientasi landasan ilmiah mengenai pendidikan yang hirau terhadap nilai-nilai kemanusiaan, sesuatu yang selama ini luput dari perhatian dikarenakan kurangnya studi tentang landasan budaya pendidikan.

Menurut Suratno (2010), keutamaan pendidikan hendaknya jangan sampai tereduksi menjadi hal-hal yang superficial, sebagaimana terjadi kini pada rezim standarisasi, sehingga mengabaikan tujuan luhur dari pendidikan itu sendiri, yaitu pendidikan yang membudayakan.

Berdasarkan analisis terhadap dimensi budaya dan pendidikan oleh Suratno (2010), memandang Etnopedagogi sebagai praktik pendidikan berbasis kearifan lokal dalam berbagai ranah serta menekankan pengetahuan atau kearifan lokal sebagai sumber inovasi dan keterampilan yang dapat diberdayakan demi kesejahteraan masyarakat, yakni kearifan lokal tersebut terkait dengan bagaimana pengetahuan dihasilkan, disimpan, diterapkan, dikelola dan diwariskan.

Etnopedagogi sebagai praktik pendidikan berbasis kearifan lokal nampaknya sejalan dengan temuan Alexander dalam Suratno (2010) yang menunjukkan terdapat hubungan yang erat antara pedagogi dengan kehidupan sosial budaya masyarakatnya. Hal demikian juga sejalan dengan pandangan Bernstein (Bernstein \& Solomon, 1999, dalam Suratno, 2010) yang menyatakan "How a society selects, classifies, distributes, transmits and evaluates the educational knowledge it considers to be public, reflects both the distribution of power and principles of social control'.

Menarik apa yang dikemukakan oleh Suratno (2010) tentang upayanya untuk memposisikan etnopedagogi secara lebih strategis, pertama, etnopedagogi dapat berperan dalam pendidikan berbasis nilai budaya bagi pengajaran dan pembelajaran dalam konteks teaching as cultural activity Stigler \& Hiebert (1999) dan the culture of teaching. Di sisi lain, etnopedagogi berperan dalam menciptakan secara berantai kader-kader yang memiliki kecerdasan kultural dan konteks pendidikan guru.

Oleh karena diperlukan tindakan untuk mengangkat kembali nilai-nilai kearifan lokal sebagai sumber inovasi dalam bidang pendidikan berbasis budaya masyarakat lokal, dengan cara melakukan pemberdayaan melalui adaptasi pengetahuan lokal, termasuk reinterpretasi nilainilai kearifan lokal, dan revitalisasinya sesuai dengan kondisi kontemporer. Selain itu diperlukan kerjasama yang kuat antara pemerintah daerah, perguruan tinggi dan budayawan untuk revitalisasi nilai-nilai kearifan lokal maupun mengembangkan konsep-konsep akademik, melakukan uji coba model-model etnopedagogi dalam pembelajaran Anan-Nur (2010).

Etnopedagogi pada kurikulum 2013 dilandaskan pada Peraturan Menteri Pendidikan dan Kebudayaan Republik Indonesia Nomor 79 Tahun 2014 menjelaskan bahwa pembelajaran baik ditingkat sekolah dasar/madrasah ibtidaiyah sampai pada sekolah menengah atas/sekolah menengah kejuruan harus bermuatan lokal yang merupakan bahan kajian atau mata pelajaran pada satuan pendidikan yang berisi muatan dan proses pembelajaran tentang potensi dan keunikan lokal yang dimaksudkan untuk membentuk pemahaman peserta didik terhadap keunggulan dan kearifan di daerah tempat tinggalnya.

Tilaar (2015) menjelaskan bahwa kearifan lokal mempunyai nilai pedagogis untuk mengatur tingkah laku yang bermanfaat bagi kepentingan bersama masyarakat. Kajian ini sesuai dengan Peraturan Menteri Pendidikan dan Kebudayaan Republik Indonesia Nomor 79 Tahun 2014 pasal 2 ayat (2) menjelaskan bahwa muatan lokal 
diajarkan dengan tujuan membekali peserta didik dengan sikap, pengetahuan, dan spiritual di daerahnya. Tujuan lainnya yaitu melestarikan dan mengembangkan keunggulan dan kearifan daerah yang berguna bagi diri dan lingkungannya dalam rangka menunjang pembangunan nasional.

Pembelajaran yang berorientasi etnopedagogi sangat penting diterapkan mengingat Indonesia merupakan negara majemuk yang terdiri dari berbagai suku bangsa dan etnis yang tentunya memiliki budaya yang berbeda-beda. Kedua, globalisasi dan perkembangan teknologi dapat menyebabkan perubahan budaya pada masyarakat Indonesia.

Jika pembelajaran berorientasi pada etnopedagogi tidak diterapkan sejak dini, maka masa yang akan datang globalisasi dan perkembangan teknologi yang sangat pesat dapat menggeser kearifan lokal dalam masyarakat. Pergeseran ini terjadi karena tidak adanya batasan yang jelas antara budaya lokal dan budaya asing. Kondisi ini jelas menunjukkan bahwa pendidikan di Indonesia perlu menerapkan pembelajaran yang berorientasi pada kearifan lokal.

Bagi Sularso (2016), proses pendidikan dengan menjadikan kearifan lokal penting untuk direalisasikan sebab kearifan lokal sudah mulai terabaikan yang terlihat dari perilaku kehidupan sehari-hari yang tidak mewujdukan nilai-nilai kearifan lokal dan lokalitas tergerus oleh tatanan gaya hidup yang di dalamnya mengandung nilai pragmatis-kapitalistik. Sementara itu, hal tersebut didukung oleh pendapat Syaifulloh (2017) yang menyatakan bahwa Syair Gulung sebagai kearifan lokal masyarakat Melayu Kabupaten Ketapang Kalimantan Barat memiliki nilai pendidikan kebencanaan.

\section{d. Kajian Etnopedagogi terhadap Yoga sebagai Tradisi Bali}

Dari gambaran di atas, dapat kita jelaskan beberapa aspek sebagai deskripsi mengenai bagaimana Yoga dikatakan sebagai suatu tradisi di
Bali melalui suatu kajian pendidikan yang selaras dengan budaya atau kearifan lokal.

Salah satu aplikasi Yoga dalam kehidupan sehari-hari yaitu sembahyang. Menurut Pandit (2005), sembahyang merupakan ajaran Bhakti - Yoga, dimana Bhakti Yoga adalah jalan bagi pengabdian diri, pemujaan, dan penyerahan diri kepada Tuhan. Para pemuja dalam jalan ini memuja Tuhan dalam berbagai bentuk yang ia punyai. Jalan ini adalah penyadaran yang sesuai dengan orang-orang yang terberkahi dengan pikiran yang emosional. Para pemuja dalam jalan ini secara inisial memilih salah satu Dewa (IstaDewa), yang sesuai temperamen dirinya, untuk mewujudkan tujuan spiritual. Tujuan dari jalan spiritual adalah melebur ego dari seorang individu melalui pengabdian dan penyerahan diri pada keinginan Tuhan.

Pendapat lainnya oleh Sivanandha (2003), Bhakti merupakan kasih sayang yang mendalam kepada Tuhan. Mereka yang mencintai Tuhan tak memiliki keinginan ataupun kesedihan, ia tak pernah membenci mahluk atau benda apapun dan tak pernah tertarik dengan objek-objek duniawi, ia merangkul semuanya dalam dekapan hangat kasih sayangnya.

Hal ini didukung pula oleh Suhardana (2004) yang menyebutkan sembahyang dapat memelihara kesehatan seseorang. Dengan melakukan Asana atau sikap duduk Padmasana, dimana tulang punggung, leher dan kepala harus tegak lurus (tidak membungkuk), kemudian dengan Pranayama (pengaturan nafas) dengan sikap batin yang hening, tenang dan suci, akan menjadikan tubuh seseorang semakin sehat

Contoh lain adalah menghormati orang tua. Paramahamsa Yogananda (dlm Autobiography of a yogi) menguraikan bahwa jika dalam sehari saja kita dapat membahagiakan, mematuhi dan menghormati Orang Tua dan Guru hanya dengan menghormati dan menyayangi orang tua, kita sudah dianggap berlatih yoga selama delapan 
jam secara intensif di bawah bimbingan Guru sejati serta dianggap telah melakukan perjalanan evolusi yang seharusnya ditempuh secara alami selama seribu tahun. Melalui Bhakti Sang Yogi memperoleh kedekatan hubungan dengan Tuhan sebagai pribadi kosmik tertinggi (Para Brahman) Yoga belumlah sempurna tanpa Bhakti, sehingga sering dikatakan bahwa Bhakti merupakan puncak dari segala yoga.

Ahimsa juga termasuk kebiasaan dalam bermasyarakat yang apabila dilaksanaakan merupakan aplikasi dari Yoga. Dalam buku yang berjudul Disiplin dan Sadhaana Spiritual, kegiatan tersebut merupakan ajaran yoga dimana tidak membunuh merupakan ajaran daripada Ahimsa. Ahimsa merupakan bagian dari pada astangga yoga, Ahimsa merupakan tahap awal untuk mengendalikan diri. Jika tahap awal ini gagal dicapai maka sulit atau tidak bisa untuk mencapai tahap yang lebih tinggi yaitu Samadhi.

"Engkau tidak boleh menggunakan tubuh yang diberikan Tuhan untuk membunuh makhluk Tuhan, apakah mereka manusia, binatang atau apapun." (Yajur Veda Samhita 12.32)

Yang dimaksud tidak menyakiti makhluk lain yaitu tidak membunuh binatang sembarangan, kita harus mengasihi makhluk tersebut. Ini termasuk kedalam Ahimsa salah satu ajaran yoga. Walaupun ahimsa secara umum berarti sebagai kebajikan dari pendeta Budha dan Jainisme, akarnya tumbuh dalam Veda dan Upanisad yang subur yang merupakan kitab Hindu yang utama. Ahimsa mengajarkan bahwa seseorang harus menganggap semua makhluk hidup adalah perlambang dari Tuhan dan sehingga seseorang itu tidak boleh melukai pikiran, dengan kata-kata atau perbuatan mahluk lainnya.

Menurut Zoetmulder (1995), disebutkan bahwa konsentrasi juga aplikasi dari Yoga yang merupakan tindakan memegang, membawa, menguasai, dan memiliki. Maharsi Patanjali mengajarkan 3 cara dharana, yaitu: (1) menguasai indra-indra agar tetap terkonsentrasi pada satu objek saja, tetap dibawah pengawasan manah (pikiran), (2) menentramkan gerak-gerik pikiran dengan watak lemah lembut, ceria, penuh kasih sayang dan tenang baik dalam keadaan duka maupun suka, (3) mengkonsentrasikan indra tersebut pada nafas yang keluar masuk tubuh (Yogasutra, I:32-25).

Menurut Pandit (2005), Dharana yang merupakan pengkonsentrasian pikiran terhadap suatu objek. Tanpa kosentrasi, kita tidak dapat memiliki suatu keberhasilan dalam jalan kehidupan. Pada seorang manusia duniawi, pancaran pikiran berpencar kesegala arah, melompat-lompat seperti seekor kera. Sekali saja Pratyahara telah dapat dilakukan, pikiran kemudian diarahkan kepada objek konsentrasi. Objek tersebut dapat berupa gambaran dari Dewa, sebuah mantra, nafas seseorang atau bagian tubuh, atau hal yang lain.

Aplikasi Yoga lainnya adalah dengan melakukan renungan atau merenung. Dalam ajaran Yoga dikenal istilah Dhyana. Menurut Zoetmulder (1995), Dhyana adalah meditasi, refleksi, atau pemusatan pikiran, disebut juga kontemplasi atau renungan mendalam. Maharsi Patanjali menjelaskan "tatra pratyaikatanata dhyanam" artinya, "arus pikiran terkonsentrasi tak putus-putusnya pada objek renungan" (Yogasutra, III:2). Hal ini didukung oleh Sukayasa (2006) yang menyatakan bahwa seperti halnya air sungai yang menuju laut, demikian pulalah hendaknya renungan itu terpusat pada Isvara "Tuhan". Renungan mendalam itu sesungguhnya adalah Samadhi. Orang yang merenung (pemikir), aktivitas merenungnya (pemikirannya), dan yang direnungkan (objek yang dipikirkan)

\section{PENUTUP}

Dari pemaparan diatas adapun yang dapat disimpulkan bahwa dalam pelaksanaan Yoga baik Asanas, Pranayama, atau yang lainnya, telah menjadi suatu perilaku yang secara tidak 
langsung menjadi kebiasaan dalam kehidupan bermasyarakat. Dalam kajian etnopedagogi, dapat dijelaskan bahwa segala perilaku yang dilaksanakan dalam bermasyarakat memang merupakan aplikasi dari ajaran Yoga. Inilah yang disebutkan sebagai kajian pendidikan yang didasari dengan kearifan lokal budaya setempat.

\section{DAFTAR PUSTAKA}

Admin. 2012. Pengertian Yoga. (Online). (http://niatingsun.blogspot.com/2012/03/ pengertian-yoga.html/, diakses 2 Agustus 2018)

Avadhutika, Anandamitra, Acarya. 2001. Yoga Untuk Kesehatan. Jakarta: Persatuan Ananda Marga Indonesia

Clifford, G. 1980. Kebudayaan dan Agama, terj. Francisco Budi Hardiman, Yogyakarta: Kanisius.

Dunia Fitnes.com. 2012. 4 Manfaat Yoga Bagi Si Super Sibuk. (Online). (http://duniafitnes. com/health/4-manfaat-yoga-bagi-si-supersibuk.html/, diakses 2 Agustus 2018)

Fukuyama, Francis. 1999. Social Capital and Civil Society.The Institute of Public Policy, George Mason University.

Geriya, I Wayan. 2000. Pariwisata \& Dinamika Kebudayaan Lokal, Nasional, Global. Denpasar: Upada Sastra.

Harsawardana, Susan. 2011. Konsep Terapi Yoga. (Online). (http://susanharsawardana. wordpress.com/2011/10/25/konsep-terapiyoga.html/, diakses 2 Agustus 2018)

Hartini, Sri. 2002. Surya Namaskar. Surabaya: Paramita

Prabhat Ranjan Sarkar. 2003. Psikologi Yoga. Jakarta: Persatuan Ananda Marga Indonesia

Ritzer, George-Douglas J. Goodman. 2007. Teori Sosiologi Modern. Jakarta : Kencana Predana Media Group. Sad Guru Sant Keshavadas (Agus S. Mantik). 2000. Gayatri, Semedhi
Mahatinggi, Denpasar: PT Pustaka Manikgeni Sauri, Sofyan. 2006. Pendidikan Berbahasa Santun. PT genesindo. Bandung

Shangkala. 2009.Pengertian Yoga.(Online).(http:// artshangkala.wordpress.com/2009/10/07/ pengertian-yoga/, diakses 2 Agustus 2018)

Sita, Nadia. 2010. Apakah Arti, Tujuan, dan Manfaat Yoga. (Online). (http://sitaaerobic. blogspot.com/2010/03/apakah-arti-tujuandan-manfaat-yoga.html/, diakses 2 Agustus 2018)

Swami Niranjanananda Saraswati. 2006. Yoga and Expansion of Consciousness. Colombia: The National University

Svami Satya Prakas Saraswati. 2002. Patanjali Raja Yoga. Surabaya: Paramita. 